Acta Universitatis Wratislaviensis No 3787

Studia Linguistica XXXVI Wrocław 2017

DOI: $10.19195 / 0137-1169.36 .3$

НАТАЛІЯ ЄВСТАФІЇВНА ДРАЧ

Київський університет імені Бориса Грінченка, Ukraine

\title{
Реалізація лінгвістичної економії в німецькій мові за допомогою абсентивних інфінітивних конструкцій
}

Однією з визначних характеристик сьогоденного суспільства $є$ багатомірність процесів глобалізації, які детерміновані стрімким розвитком інформаційних технологій. Тотальна інформатизація $\epsilon$ ключовою установкою соціальної еволюції людської спільноти та однією з головних передумов виникнення та існування „мережного суспільства”. Високотехнологічні інформаційні мережі, що існують сьогодні у вимірах світового масштабу призводять до того, що інформація постає основним предметом масового продукування та споживання. Іїі обсяг, який безупинно збільшується, висуває чітко визначені вимоги до головного засобу іiі передачі - людської мови.

Розвиток інформаційного простору, його інтенсивне ущільнення вимагають від мови адекватно реагувати на зміну умов комунікації, яка все більше стає технічно опосередкованою. Щохвилинно реалізуються мовленнєві акти найрізноманітнішого характеру (запит інформації, іiі підтвердження, заперечення, схвалення тощо) за допомогою електронно-технічних засобів, які, в свою чергу, безперервно оновлюються та розширюють можливості комунікативної взаємодії. Контактування в соціальних мережах, за допомогою скайпу, мобільного зв'язку тощо дозволяє нам спілкуватися за будь-яких умов швидко, мобільно, оперативно. Проте збільшення обсягу та щільності інформаційних потоків створюють тиск, який помітно впливає на самі мовні засоби, вимагаючи від них бути відповідно щільними, чіткими, лаконічними, економними, змушують мову відповідно розвиватися, позбавляючись всього зайвого, незадовільно обгрунтованого, непотрібного, всього того, що могло б ускладнювати функціонування мовлення в процесі спілкування.

Мова, як універсальна та гнучка система, дозволяє своїм користувачам відшукати серед арсеналу своїх засобів такі, які б оптимально відповідали 
цілям та умовам комунікації. Так, наприклад, спостерігаємо останнім часом в німецькій мові стрімке збільшення словникового запасу за рахунок скорочень (Abo, Azubi, Franze, Info, Medi, OP, Prof, Schoko, Spüli ...), повсюдне використання англіцизмів (joggen, walken, Team, abchecken, auspowern, cash, Chat, Champ, Entertainer, Doping), спрощення шляхом поширення номінального стилю (Regelung, Abrüstung, Einsatz, Planung, Rezession) тощо (Куорті 2010:2). Широким попитом користуються не тільки економні лексичні одиниці, але й прості лаконічні граматичні конструкції, які уможливлювали б економну передачу достатньої кількості інформації. Існуючі загальноприйняті граматичні конструкції під впливом часу знаходять собі аналоги серед більш зручних, простих та адекватних ситуації спілкування структур.

Питання виникнення та поширення однієї з таких відносно нових узуальних граматичних конструкцій постало в центрі нашої дослідницької уваги. Наразі існує ряд мовознавчих досліджень, присвячених абсентиву. Зокрема описано основні лексико-семантичні та морфолого-синтаксичні ознаки абсентивних інфінітивних конструкцій, проведено зіставний аналіз абсентиву з прогресивними конструкціями, на основі емпіричних даних здійснено спробу виділити основні дидактичні аспекти стосовно впровадження даних конструкцій у викладацьку практику. Нез'ясованими та вартими уваги залишаються, на наш погляд, інтралінгвістичні причини виникнення абсентивних інфінітивних конструкцій. Тому основною метою даної розвідки є обгрунтування появи та функціонування зазначених конструкцій, зумовлених дією в мові лінгвістичної економії.

На сучасному етапі розвитку мови ми спостерігаємо тенденцію, суть якої полягає в тому, щоб звести до мінімуму затрати сил учасника комунікації, його прагнення передати якомога більше інформації за рахунок мінімальних зусиль, при цьому не порушити доступність і розуміння змісту. Вирішальним аспектом для сучасної електронно-опосередкованої комунікації з іiї лімітом використовуваних засобів (наприклад регламентована мобільним оператором кількість позначень для одного смс-повідомлення) стає лінгвістична економія, яка може мотивувати створення нових виражальних можливостей.

Саме поняття лінгвістичної економії не є новим, його дослідження має досить довгу історію. Тенденцію економії мовних зусиль як одну з найсуттєвіших внутрішніх тенденцій розвитку мовної системи, що має прояв в усіх мовах світу, визнавали Г. Пауль, Г. Спенсер, Є. Поліванов, А. Мартине, Дж. Ціпф та інші.

Гарвардський професор Дж. К. Ціпф, базуючись на біхевіорістичній теорії, розглядає мовленнєву поведінку як таку, що регулюється принципом мінімальних зусиль людини. В своїй роботі „Human Behavior And The Principle Of The Least Effort“ він робить спробу дефінувати принцип „Least Effort“ в сенсі редукування власних зусиль настільки, наскільки це $є$ можливим для задоволення потреб в повідомленні інформації, іiі обміні тощо. 
„Мета кожного мінімізувати середньостатистичні затрати зусиль протягом всього життєвого шляху" (Куорті 2010:5). Цей принцип визначає загальну поведінку людини, включаючи також ії̈ ментальну активність. Мова людини і постає тією когнітивною активністю, в якій Дж. К. Ціпф вбачає суттєвий економічний потенціал.

А. Мартине був одним з перших, хто використав поняття „мовної економії” для запропонованого Дж. К. Ціпфом концепту. Французький теоретик структуралізму розглядає антиномію між комунікативними потребами людини та її прагненням звести до мінімуму свою розумову і фізичну діяльність. На його думку, принцип лінгвістичної економії є визначним у змінах мовної системи. Він сприяе не тільки усуненню надлишкових мовних засобів, але й збереженню існуючих та виникненню нових мовних елементів, обумовлюючи таким чином „синтез” задіяних в мові процесів (Мартине 1960:130).

Отто Есперсен, як автор „теорії прогресу” в мові, визнає прогресивний характер її розвитку в цілому, та вбачає мовні зміни як такі, що спрямовані на полегшення умов комунікації. Згідно з його положеннями тільки економні мови здатні досягти найбільшої виразності при найменшій затраті зусиль.

Аналіз досліджень багатьох інших мовознавців підводить нас до розуміння того, що лінгвістична економія не є виключно явищем абсолютного спрощення або тотального редукування виражальних засобів. Процеси оптимізації комунікативної взаємодії базуються на мінімізації людських зусиль, і не завжди на мінімізації мовних засобів. Г. Пауль підкреслював, що економія - не веде до однозначного звуження ресурсів мови, навпаки, в комплексі з іншими факторами, вона забезпечує розширення іiі ресурсів, ліквідуючи надмірності (Пауль 1995:127). Ілюстративним прикладом цьому може слугувати зникнення синтетичних форм кон'юнктиву (tränke, hülfe, fröre) в сучасній німецькій мові та заміна їх аналітичними формами 3 допоміжним дієсловом würde (würde trinken, würde helfen, würde frieren).

Таким чином, виходячи з лінгвістичної економії, спостерігаємо сьогодні серед процесів мовних змін дві протилежні тенденції, одна з яких має ознаки врівноваженості, є спрямованою на спрощення та ущільнення виражальних засобів, інша, навпаки, має диференційований аналітичний характер.

Яскравим прикладом здійснення цих тенденцій в мовній реальності $\epsilon$ приживання конструкцій, які б відповідали сучасному етапу розвитку мови та претендували б на право в найближчому майбутньому набути статус мовної норми і перейти з сфери живого спілкування в область літературної мови.

Так, наприклад, новоявлена граматична конструкція абсентиву, навколо якої і досі ведуться активні дискусії серед мовознавців, є відображенням свідомого прагнення носіїв німецької мови висловлюватися лаконічніше, простіше, зрозуміліше. Останніми роками інфінітивні граматичні конструкції абсентиву виступають предметом критичного аналізу значної кількості західних лінгвістів. Проблему визначення абсентивних граматичних кон- 
струкцій намагалися розкрити у своїх працях В. Абраам, П. Айзенберг, Г. Глюк, Е. Генчель, П. М. Фогель, Л. Гофманн, О. Краузе та багато інших.

Формально презентована формулою „фінітного дієслова - зв’язки sein та інфінітиву смислового дієслова" (Wir sind essen) дана структура існує поза межами традиційної граматики німецької мови, а отже і поза літературною нормою. Проте завдяки своїй відповідності нагальним вимогам часу бути спрощеною економною граматичною конструкцією, вона стрімко набуває статусу загально вживаної. За умови розгляду останньої як такої, що існує поза мовною нормою, можна кваліфікувати ії як помилку, певне порушення норми. Однак якщо відповідні порушення виступають настільки часто, що проникають iз сфери усного спілкування в область публіцистики та художньої літератури, вони отримують свого роду ліцензію існувати поруч з літературною нормою, з часом стати нею і витіснити менш доречну стару. Це визнавав ще на початку минулого століття Отто Есперсен. У своїй „Філософії граматики” він стверджував, що ,язык не таков, каким он нам представляется при одностороннем изучении его по словарям и обычным грамматикам. Язык - это совокупность навыков, привычных действий, а каждое слово и каждое произнесенное предложение есть сложное действие со стороны говорящего. Большая часть этих действий определяется тем, что говорящий сам делал в подобных ситуациях, а последнее, в свою очередь, тем, что ему приходилось неоднократно слышать от других. Но в каждом конкретном случае (если не считать воспроизведения обычных формул) говорящему приходится применять языковые навыки к данной ситуации, чтобы выразить то, что во всех подробностях никогда до этого не выражалось. И поэтому он не может быть рабом этих навыков; он должен приспосабливать их к изменяющимся потребностям. В результате могут возникнуть новые навыки и привычки или, иначе говоря, новые грамматические формы и новые правила их употребления" (Есперсен 1958:14). Такий підхід щонайбільше підходить для обгрунтування права абсентивних граматичних конструкцій існувати в граматиці сучасної німецької мови. Це право обумовлене виконанням нею в граматиці чітко окресленої функції, а саме бути засобом вираження ознаки абсентивності (англ. 'absent', нім. 'abwesend' - вiдcyтній). Мова йде про вираження відсутності агенса дії, вираженої основним смисловим дієсловом. Спробуємо розглянути дану граматичну конструкцію з точки зору лінгвістичної економії. Вочевидь абсентивна інфінітивна конструкція $€$ простою лаконічною синтаксичною структурою, вираженою суб'єктом та складним дієслівним присудком. Локалізацією ії виникнення являється живе усне спілкування, насамперед діалогічне мовлення, яке, в свою чергу, і постає саме тією сферою, де принцип лінгвістичної економії знаходить своє найкоректніше застосування. Саме розмовна мова містить найбільшу кількість мовних одиниць, метою застосування яких є збереження зусиль на всіх рівнях мовної системи. „Розмовне діалогічне мовлення - це свого роду ‘кузня’, в якій створюються форми, що фактично використовуються в повсякденному житті” 
(Головач 2011:139). Зустрічаються абсентивні конструкції і в публіцистиці. Використовуючи дані мовних корпусів DWDS та LIMAS маємо достатню для аналізу кількість ілюстративних прикладів. Наведемо лише деякі 3 них:

Die spärlich eingerichtete Fünfzimmerwohnung ist schmutzig, die Kinderzimmer stehen fast gänzlich leer. Ihr Mann ist arbeiten, Ein-Euro-Job, die fünf Kinder sind nicht da . ,, Sie hatten doch eine schöne Wohnung, warum sind Sie denn umgezogen?", fragt Wolter. (Berliner Zeitung, 07.09.2005);

Zwei Wochen später in Hannover, nach der Generalprobe in einem Restaurant, trinkt Raimund Hoghe ein Glas Bordeaux. Er war spazieren in der Fußgängerzone. Da sei er auf die Bildungsministerin Edelgard Bulmahn gestoßen. (Die Zeit, 08.09.2005);

Kind überlebt Sturz aus 15 Metern Höhe Die Mutter war einkaufen. (Der Tagesspiegel, 08.08.2003);

„Ich hatte viel zu erledigen, war einkaufen.” (Jentzsch, Kerstin: Ankunft der Pandora, München: Heyne 1997 [1996], S. 190);

Als ich anrief, fertigte mich eine Kinderstimme ab: „Mami ist einkaufen und kommt erst um drei - Wiedersehn, Wiedersehn. "Ich fuhr trotzdem in die Eschersheimer Landstraße 107. (Die Zeit, 24.01.1969).

Враховуючи невербальний контекст мовленнєвої ситуації (зазвичай опосередковане технічними засобами усне спілкування), в якій реалізуються абсентивні інфінітивні конструкції, маємо підстави вважати, що причиною їх виникнення було інтуїтивне прагнення носіїв мови передати певний обсяг інформації, скоротивши та оптимізувавши процес комунікативного взаєморозуміння. Оскільки результатом принципу економії на будь-якому рівні мовної системи є скорочення мовленнєвого ланцюгу, а відповідно, редукція зусиль і часу, маємо справу з впевненим побутуванням у мовленні німців такого спрощеного уніфікованого мовного засобу як інфінітивна конструкція абсентиву. До їі основних морфолого-синтаксичних та семантичних ознак належать:

1. Наявність суб'єкта дії, відмінюваного дієслова sein та смислового дієслова, вираженого інфінітивом.

2. Наявність виконавця дії - агенса, який на момент мовлення є відсутнім, тобто віддаленим від так званого вказівного центру (deiktisches Zentrum), не в полі зору.

3. Причиною відсутності виконавця є дія, яка є закодованою у смисловому дієслові і виконується суб'єктом в іншому, відмінному від вказівного центра, місці.

4. Передбачається, що виконавець дії через певний проміжок часу повернеться до вказівного центру (Драч 2015:512). 
П. Фогель схильна вважати дію, виражену інфінітивом смислового дієслова такою, яка виконується суб'єктом на регулярній основі (наприклад в якості хобі). Більшість мовознавців підкреслюють, що основне функціональне навантаження виконує саме ознака абсентивності. Звичайно в мові існують альтернативні засоби вираження відсутності суб'єкта дії, наприклад, за допомогою обставини місця. Чому ж тоді вирази типу Er ist im Schwimmbad, Sie ist auf dem Tennisplatz все частіше витісняються абсентивними інфінітивними конструкціями Er ist schwimmen, Sie ist Tennis spielen. Можливо тому, що вираження абсентивності традиційним шляхом, а саме за допомогою обставини місця, вираженої прийменниковою групою вимагає від мовця виконання цілого ряду когнітивних операцій, таких як врахування роду іменника, вибір відповідного прийменника, співвіднесеність прийменника 3 належним відмінком, визначення відмінкової форми артикля. Натомість використання неозначеної форми дієслова значно економить мовленнєві зусилля мовця. Та найголовнішим $€$ те, що спрощення граматичної структури не призводить до iii змістової редукції, абсентивна конструкція є виправданою, оскільки повністю відповідає комунікативній потребі. Застосування інфінітиву смислового дієслова реалізує три основні комунікативні цілі:

- вказує на відсутність суб'єкта дії;

- імпліцитно виражає місце його дислокації на момент відсутності;

- $є$ засобом передачі динаміки, активності суб'єкта на момент мовлення.

Лінгвісти (В. Абраам), які виходять з позицій заперечення автономності абсентивної інфінітивної конструкції, схильні вбачати в ній еліптичну форму граматичної структури з дієсловом gehen / weggehen. Проте виявити хибність такого підходу можливо, розглянувши особливості функціонування абсентивних конструкцій в різних часових формах минулого часу. Так речення типу Michael war Fußball spielen $€$ формою простого минулого часу імперфект і не може бути еліптичним варіантом від Michael war Fußball spielen gegangen, оскільки його використання виключає ситуація спілкування, а саме недоречність використання форми складного давноминулого часу плюсквамперфект:

- War Michael gestern Abend zu Hause?

- Nein. Er war Fußball spielen.

Відповідь Michael war Fußball spielen gegangen повинна була б бути обумовленою наявністю щонайменше двох дій у минулому часі та необхідністю вираження їх послідовності, які в даній ситуації спілкування є відсутніми, а отже і використання плюсквамперфекту не $є$ виправданим і коректним. Відповідно конструкція Michael war Fußball spielen не є еліптичною формою плюсквамперфетного речення Michael war Fußball spielen gegangen, 
а виступає досить економним, раціональним відносно цілей висловлювання i тому оптимальним виражальним засобом. На семантичному рівні також просліджуються приклади, в яких використання конструкцій перфекту чи плюсквамперфекту були контекстуально немотивованими. Наприклад: Wo wart ihr? - Wir waren in der Stadt, Kaffee trinken. у порівнянні $з$ дещо алогічним висловлюванням Wir waren in der Stadt, Kaffee trinken gegangen. Наведені речення вочевидь ілюструють той факт, що абсентивна інфінітивна конструкція є самодостатнім і досить інформативним мовним засобом.

Такий спосіб, в який співрозмовник оформлює своє мовлення, а отже і саме використання абсентивної інфінітивної конструкції Michael war Fußball spielen, Wir waren in der Stadt Kaffee trinken можна пояснити за допомогою комунікативних максимів Г. П. Грайса.

Базуючись на принципах кооперації, Г. П. Грайс вважав, що „коммуникативный вклад на данном шаге диалога должен быть таким, какого требует совместно принятая цель (направление) этого диалога" (Грайс 1985:213). Г. П. Грайсом розроблені конкретні постулати, дотримання яких і здійснює виконання даного принципу. Загальний характер „Cooperative Principle“ визначений чотирма комунікативними максимами, які Г.П. Грайс услід І. Канту називає категоріями кількості, якості, відношення та способу. Будучи досить економними, абсентивні інфінітивні конструкції дозволяють в повному обсязі реалізувати постулати категорії кількості:

1. Твоє висловлювання повинно містити не менше інформації ніж це $€$ потрібним для виконання поточних цілей діалогу.

2. Твоє висловлювання не повинно містити більше інформації ніж це вимагається (Грайс 1985:217).

Пряме відношення до абсентиву мають також максими ясного висловлювання, які лежать в основі категорії способу, а саме:

1. Висловлюйся стисло. Уникай непотрібної багатослівності.

2. Будь організованим (Грайс 1985:217).

Виходячи 3 цього, можемо провести паралель 3 думкою Дж. Ціпфа та його „Principle of Least Effort”, оскільки він як і Г. П. Грайс розглядає мовленнєвий акт в якості раціональної поведінки людини, орієнтованої на мету висловлювання, яка виступає у тісному взаємозв' язку з невербальними чинниками комунікативної взаємодії. Лінгвістичну економію Грайс виправдовує не тільки з точки зору формальної побудови висловлювання, але й визнає iii найважливішою характеристикою категорії якості, яка відповідає за істинність твердження. На його думку, значно економнішим буде сформулювати істинне твердження ніж вигадувати неправду. 
На прикладі абсентивних інфінітивних конструкцій маємо можливість окреслити головні переваги змін, що відбуваються у сучасній німецькій мові для нових граматичних форм. Вони стають загалом більш лаконічними, сприяють зменшенню напруження органів артикуляції та кількості потрібної для неї часу. Це, в свою чергу, призводить до спрощеного взаєморозуміння не тільки з позицій мовця, але й з перспективи слухача. Дані конструкції $\epsilon$ уніфікованими регулярними утвореннями, які підвищують ефективність наявних в мові виражальних засобів. Вони являються також оптимальними 3 точки зору вирівнювання відмінностей між регіональною і соціальною нормою, з метою кращої відповідності комунікативним потребам. Так, наприклад, спостерігається тенденція серед засобів масової інформації до сприйняття економних змін у нормі, з метою скасування соціальних мовних бар'єрів та здійснення впливу на кожного мовця.

Сучасні засоби збереження і передачі інформації не тільки детермінують появу нових спрощених оптимальних граматичних форм, але й каталізують їх поширення (чати, електронна пошта, скайп та більшість соціальних мереж). Особливістю сучасної інформатизованої доби $є$ той факт, що кожен 3 нас із споживача перетворюється відповідно на творця тієї чи іншої мовної продукції. Всі ми сьогодні маємо можливість творити «інформаційний контент», обумовлений майже необмеженим доступом до технологій, ресурсів мовної творчості та майданчиків ії реалізації.

Г. Мозер, вивчаючи типи лінгвістичної економії в сучасній німецькій мові, спирається в якості вихідного положення на „homo novarum rerum cupidus“. Видатний німецький філолог та германіст, фундатор декількох організацій з германістики, вирішальним фактором для розвитку мовної системи та змін в ній вбачав прагнення людини відрізнятися від своїх попередніх поколінь, ії творчу схильність до нововведень, в тому числі й мовних. До того ж провідною ознакою цієї схильності вважає здійснення нового 3 якомога меншою затратою сил (Мозер 1971:92).

Унікальність абсентивних інфінітивних конструкцій полягає не тільки в їх спрощеній граматичній формі, а насамперед у тому, що незважаючи на свою економність, вони залишаються досить інформативними (уможливлюють передачу лише за допомогою складного дієслівного присудка відсутність суб'єкта дії, віддаленість його від місця, де відбувається мовленнєвий акт, та причину цієї відсутності) і здатними повністю відповідати прагматичним цілям співрозмовників. Така оптимізація обгрунтовує утвердження узуального абсентиву в сучасній німецькій мові та підкріплює доводами думку класика історії мови Г. Пауля: „Подлинной причиной изменений узуса является не что иное, как обычная речевая деятельность. Эта деятельность исключает всякое преднамеренное воздействие на узус. В ней не обнаруживается ничего иного, кроме намерения, связанного с испытываемой в данный момент потребностью сделать свои желания и мысли достоянием других" (Пауль 1960:53). 
Таким чином, дана розвідка дає можливість підтвердити припущення про наявність інтралінгвістичних факторів, які мотивують виникнення та розповсюдження в мові абсентивних інфінітивних конструкцій та визнати в якості основних рушіїв дію принципа лінгвістичної економії та пов'язаних $з$ ним комунікативних максимів П. Грайса, а саме категорії кількості та способу. Перспективним вважаємо аналіз зазначених конструкцій з позицій теорії релевантності Д. Уілсона і Д. Шпербера з метою подальшого визначення їх лексико-граматичного статусу та потенціалу бути стандартизованими в граматиці сучасної німецької мови.

\section{Список використаних джерел}

ABRAHAm Werner, 2007, Absent arguments on the Absentive: An exercise in silent syntax. Grammatical category or just pragmatic inference?, in: Language Typology and Universals. - STUF 61/4, S. 358-374.

ГоловАч Ольга. А., 2011, Принцип экономии в лингвистике, в: Вектор науки ТГУ, 3/17, C. $137-139$.

ГРАЙс Ге́рберт Пол, 1985, Логика и речевое общение, в: Новое в зарубежной лингвистике, 16 , С. $209-229$.

ДрАч Наталія, 2015, Явище абсентиву в граматиці сучасної німецької мови, в Тенденції та перспективи розвитку науки і освіти в умовах глобалізації, Переяслав - Хмельницький, С. 511 -514. Режим доступу: http://confscience.webnode.ru/

ЕСПЕРСЕН Отто, 1958, Философия грамматики, Москва.

ЗАнинА Анастасия Н., 2008, Теория экономии языковых усилий: к истории вопроса, в: Вестник ТвТУ, выпуск «Лингвистика и межкультурная коммуникация», серия Филология, C. $165-171$.

KöNIG Svenja, 2009, Alle sind Deutschland ... außer Fritz Eckenga - der ist einkaufen! Der Absentiv in der deutschen Gegenwartssprache, in: Winkler E. (Hrsg.), Konstruktionelle Varianten bei Verben, Opal, Sonderheft, S. $42-74$.

KraUSE Olaf, 2002, Progressiv im Deutschen: Eine empirische Untersuchung zum Absentiv im Kontrast mit Niederländisch und Englisch, Tübingen.

МАРтинЕ Андре́, 1960, Принцип экономии в фонетических изменениях, Москва.

MOSER Hugo, 1971, Sprache und Gesellschaft, Düsseldorf.

ПАУль Германн, 1960, Принципы истории языка, Москва.

PAUL Hermann, 1995, Prinzipien der Sprachgeschichte, Tübingen.

Vogel Petra M., 2007, Anna ist essen! Neue Überlegungen zum Absentiv in den europäischen Sprachen mit einem Exkurs zum Deutschen, in: Geist L./Rothstein B. (Hrsg.), Kopulaverben und Kopulasätze: Intersprachliche und Intrasprachliche Aspekte, Tübingen, S. 253-284.

Hentschel Elke / Vogel Petra M., 2010, Deutsche Morphologie, Berlin.

QUARTEY Sandy, 2010, Grundzüge der Sprachökonomie (unveröffent. Magisterarbeit), München. Режим доступу: http://www.grin.com/de/e-book/203654/grundzuege-der-sprachoekonomie 